УДК 373.3.091.37.01-37.07

Олексюк Наталя Василівна

завідувач відділу кадрів

Інститут інформаційних технологій і засобів навчання НАПН України, м. Київ, Україна

natawaoleksuk@ukr.net

\title{
АКТУАЛЬНІСТЬ ВИКОРИСТАННЯ МУЛЬТИМЕДІЙНИХ ЗАСОБІВ У ПОПЕРЕДЖЕННІ АГРЕСИВНОЇ ПОВЕДІНКИ МОЛОДШИХ ШКОЛЯРІВ
}

\begin{abstract}
Анотація. У публікації проаналізовано проблему агресивної поведінки молодших школярів i причини іiі виникнення. Визначено переваги використання мультимедійних засобів у попередженні агресивної поведінки школярів й описано різновиди мультимедійних засобів, які доцільно застосовувати в роботі 3 молодшими школярами. Проблема агресивної поведінки молодших школярів виступає однією 3 найголовніших проблем нашого суспільства. Адже, як зазначають більшість дослідників, одним із чинників, які сприяють формуванню агресивної поведінки дітей є вплив засобів масової інформації і застосування ігор, перегляд фільмів, мультфільмів, які провокують агресію. Одним із важливих напрямів роботи у попередженні агресивної поведінки молодших школярів $\epsilon$ підвищення компетентності вчителів, соціальних педагогів, психологів у використанні мультимедійних засобів з метою організації соціально-педагогічної діяльності.
\end{abstract}

Ключові слова: агресія, агресивна поведінка; мультимедійні засоби; молодші школярі.

\section{1. ВСТУП}

Постановка проблеми. На сьогоднішній день використання інформаційнокомунікаційних технологій є невід'ємною складовою освітнього процесу, адже вони стали ефективним засобом реалізації принципів наочності, доступності, систематичності та послідовності, науковості, сприяють підвищенню інтересу до навчання. У сучасних умовах масової комп'ютеризації й інформатизації всіх сторін життя суспільства перед системою освіти постають нові завдання, які вимагають пошуку шляхів у розв'язанні різноманітних соціально-педагогічних проблем та інноваційних методів управління ним.

Освітньо-педагогічний простір - важливий компонент у вирішенні соціальнопедагогічних проблем, зокрема проблеми агресивної поведінки молодших школярів. Адже, соціально-економічна криза, політична нестабільність, ситуації громадянських сутичок і конфліктів, а також відображення цих подій у засобах масової інформації, девальвація сімейних цінностей, послаблення виховного впливу 3 боку батьків сприяють підвищенню рівня дитячої агресивності. Особливо важливим є вивчення агресивної поведінки в молодшому шкільному віці, коли ця риса перебуває в стадії свого становлення й коли ще можна своєчасно іiі попередити $з$ метою запобігання агресивності як стійкої характеристики особистості.

Аналіз останніх досліджень i публікацій. Проблема впровадження мультимедійних засобів в освіті розглянуто в працях вітчизняних i зарубіжних науковців. Результати дослідження, пов’язані з використанням мультимедійних засобів навчання у загальноосвітніх навчальних закладах знаходимо у працях В. Бикова [8], Ю. Жука [8], С. Іванової [8], О. Пінчук [11], О. Соколюк [11] та інших дослідників. Опис практичного досвіду застосування мультимедійних засобів у початковій школі $з$ різних дисциплін вивчали В. Андрієвська [2], Ю. Громова, О. Литвиненко [2], I. Мураля, Н. Олефіренко [2], Л. Югова [8] та ін. 
У працях Ю. Дорошенка [2], Л. Івасишиної, А. Сршова [12], В. Коваленко [11], В. Кобак [8] та ін. досліджувались окремі аспекти використання комп'ютера у практиці початкового навчання, закладено методичні засади формування основ інформаційної культури учнів молодшого шкільного віку, висвітлено теоретичні положення підготовки вчителя початкової школи до використання інформаційно-комунікаційних технологій у професійній діяльності.

Проблему агресивної поведінки розглянуто у роботах дослідників: Л. Божовича [3], Л. Виготського [3], Д. Ельконіна [3], Е. Еріксона [1], Ж. Піаже [1], I. Кона [13] та ін. Різні особливості проявів агресивної поведінки дітей і підлітків вивчали О. Мізерна, I. Мазоха [13], О. Тарасова [14], I. Федух [19]. Чимало праць присвячено вивченню різноманітних форм агресивної поведінки дітей (О. Бовть [3], Р. Благута [3] та ін.), проблем агресивності у зв'язку з конфліктами (Г. Васильєва [16], В. Ковальов [16] та ін.), вивченню особливостей розвитку емоційної сфери у дітей дошкільного та молодшого шкільного віку (В. Мухіна [6] та ін.).

У роботах вказаних авторів розкрито питання розроблення загальних теорій використання мультимедійних технологій в освіті, особливості розвитку дітей молодшого шкільного віку і різноманітні форми агресії й агресивної поведінки. Проте, у літературі недостатньо розкрита специфіка попередження агресивної поведінки молодших школярів за допомогою мультимедійних засобів і технологій. I тому розгляд даного питання $є$ актуальним для теперішнього часу.

Мета статті: охарактеризувати актуальність використання мультимедійних засобів у попередженні агресивної поведінки молодших школярів.

\section{2. МЕТОДИ ДОСЛІДЖЕННЯ}

Для проведення дослідження було використано комплекс методів, зокрема аналіз, синтез, порівняння, узагальнення для вивчення зарубіжної і вітчизняної наукової літератури щодо змісту ключових понять; порівняння, вивчення та узагальнення педагогічного досвіду з проблеми дослідження.

\section{3. РЕЗУЛЬТАТИ ДОСЛІДЖЕННЯ}

На сьогоднішній день комп'ютер став невід'ємною складовою людського життя. Стрімкий розвиток мультимедійних технологій, тобто різноманітних видів одержання i збереження, обробки та передачі даних відкриває нові можливості для застосування комп'ютерів в освітньому процесі.

Поняття «мультимедіа»є багатогранним. Мультимедіа (від англ. слова «multi»багато і від лат. «меdia» - носій, засіб, середовище, посередник) - це спеціальна інтерактивна технологія, поєднання спеціальних технічних засобів i програмного забезпечення, що дозволяє на якісно новому рівні сприймати, переробляти і надавати різноманітні дані: текстові, графічні, звукові, анімаційні, телевізійні тощо. Мультимедіа часто вживається як аналог терміну «засоби масової комунікації» (друк, фотографія, радіо, кінематограф, телебачення, відео, мультимедійні комп'ютерні системи, Інтернет) [10]. Ю. Шафрін трактує мультимедіа як спеціальну технологію, яка дозволяє за допомогою програмного забезпечення і технічних засобів об'єднувати на комп'ютері звичайні дані (текст і графіку із зображеннями, що даються в динаміці). На думку Д. Гаєскі, мультимедіа - це такі інтерактивні комунікаційні системи, що запускаються комп'ютером і здатні створювати, зберігати, передавати і відтворювати відео, текстові, графічні та аудіо дані. Р. Гуревич дає таке трактування цього терміна: «Мультимедіа $є$ 
новою інформаційною технологією, тобто сукупністю прийомів, методів, способів продукування, обробки, зберігання, передавання аудіовізуальної інформації, заснованою на використанні компакт-дисків» [9].

Учені зробили висновки, що використання інформаційних технологій значно підвищує зацікавленість дитини у навчанні, робить процес засвоєння нових знань й уявлень про довкілля більш швидким i різнобічним, сприяє вдосконаленню i закріпленню набутого матеріалу, розвиває логічне мислення, покращує пізнавальну активність, сприяє розвитку багатьох психічних процесів.

Нині використання мультимедійних засобів $є$ необхідною освітньою технологією завдяки іiі інноваційності, цікавості та гнучкості. Використання їх на уроці допомагає структурувати і візуалізувати дані, сприяти мотивації учнів, активізації їх пізнавальної діяльності, як на свідомому, так і на підсвідомому рівні. Під час використання мультимедійних технологій у своїй роботі педагог сприяє не лише підвищенню ефективності навчальної діяльності учнів, їх пізнавальній активності, але й розв' язанню соціально-педагогічних проблем. Однією 3 таких проблем $\epsilon$ агресивна поведінка молодших школярів. Агресивна поведінка найчастіше розуміється як мотивовані зовнішні дії, що порушують норми і правила існування, що завдають шкоди, причиняють біль і страждання людям [4].

Слово «агресія» походить від латинського «aggressio», що означає «нападати». 3 точки зору філософії, агресивність розглядалась у контексті вивчення людини як духовної цінності. Дж. Локк [17] вважав, що душа (психіка) дитини $є$ «tabula rasa» (чистою дошкою), на якій відбивається життя. Так, своїм прикладом батьки можуть заохочувати жорстокість у своїх дітях: «якщо їх з малих років вчили, що можна бити та ображати інших, то чи не цим вони готуються до того, щоб робити те ж саме, коли вони стануть достатньо сильними? » [17]. Філософи, вивчаючи людину, іiі психіку, наголошували на тому, що дітей потрібно виховувати змалечку, і вплив батьків, їх стиль спілкування, агресивність породжує «душу» дитини.

3 погляду психології, агресивність трактують як тенденцію, яка проявляється в реальній поведінці чи фантазії, з метою підпорядкування собі інших чи домінування над ними [19].

Р. Берон і Д. Річардсон вважають, що агресія, не зважаючи на форму іiі прояву, $\epsilon$ поведінкою, яка спрямована на спричинення шкоди або збитку іншій живій істоті, яка має всі підстави уникати подібного поводження із собою [4]. На думку академіка Г. Паренса, агресія - це злісна, неприйнятна поведінка, що спричиняє біль навколишнім [17]. I. Звєрєва вважає, що агресивність - властивість особистості, виражена в готовності до агресивної поведінки. Агресивна поведінка - це дія, яку спонукає агресія та агресивність [14].

У своїй публікації Ю. Орлов відзначає, що агресія може здійснюватись реально, символічно або в уяві. Прикладом символічних агресивних дій є розривання паперу, гримання дверима. Уявна агресія $є$ умовним програванням сценарію агресивної поведінки [1].

Як стверджував В. Аверін, агресивна поведінка - це цілеспрямована й навмисна поведінка, тобто це свідома поведінка людини [1]. Український вчений С. Гончаренко вважає, що агресивність у дітей $є$ наслідком поганого ставлення до них (брак чуйності й поваги, надмірна строгість, зловживання покараннями) [3; 7].

Варто зазначити, що важливу роль у становленні агресивної поведінки відіграють навчання i виховання. Р. Кратчфілд i Н. Левісон визнають, що над агресивними проявами можливий контроль. Цей контроль пов'язаний 3 процесами научання контролю власних агресивних прагнень і вираження їх у формах, прийнятних у рамках даної цивілізації. У результаті соціалізації більшість дітей вчаться регулювати свої 
агресивні імпульси, адаптуючись до вимог суспільства. Інші ж залишаються досить агресивними, але вчаться проявляти агресію більш тонко: через словесні образи, приховані примуси, завуальовані вимоги та інше. Треті проявляють свої агресивні імпульси у фізичному насильстві. I тут важливу роль відіграє ранній досвід виховання дитини в конкретному культурному осередку, сімейні традиції й емоційний фон у родині, ставлення батьків до дітей.

Загальновідомо, що молодший шкільний вік - це особливий період у житті дитини. Молодший шкільний вік називають вершиною дитинства. Дитина зберігає багато дитячих якостей: легковажність, наївність, але змінюються інтереси, цінності дитини. Вона вже починає втрачати дитячу безпосередність у поведінці, у неї з'являється інша логіка мислення. Навчання для неї - значуща діяльність. У школі дитина одержує не лише нові знання й уміння, але і певний соціальний статус. Змінюються інтереси, цінності дитини, увесь иї життєвий устрій.

У психологічні літературі зазначено, що цей період супроводжується кризою 7-ми років. Це криза саморегуляції, яка виникає на основі особистої свідомості. Дитина починає регулювати свою поведінку правилами. Раніш слухняна, вона раптом починає пред'являти претензії на увагу до себе. У поведінці з`являється, з одного боку, демонстративна наївність, що інтуїтивно сприймається оточуючими як неправдива. 3 іншого боку, з'являється вимогливість до оточуючих. Для дитини розпадається єдність афекту й інтелекту. У цей період вона повною мірою не володіє своїми почуттями (не може стримувати, але й не вміє управляти ними). Втративши одні форми поведінки, дитина ще не набула інші, тому намагається за допомогою агресії задовольнити своє бажання бути визнаною і захищеною.

У цьому віці діти вступають до школи. Перший рік навчання в школі - дуже складний переломний період у житті дитини. Зі зміною соціальної ситуації, змінюється весь склад життя дитини, місце в системі суспільних відносин, зростає психоемоційне навантаження, до якого потрібно пристосовуватися [6].

Адаптація до нових вимог нерідко супроводжується різноманітними проявами агресивної поведінки. У дітей молодшого шкільного віку більш частими стають агресивні хобі і спалахи вербальної агресії. Частіше проявляється агресія по відношенню до слабких учнів у формі насмішок, тиску, образ, бійок. Ініціаторами агресії $є$ не окремі особистості, а угрупування дітей, агресивна поведінка стає більш організованою. Інструментальна агресія поступово змінюється конструктивним способом досягнення мети, а ворожа деструктивність залишається незмінною. Окрім цього, діти все частіше намагаються розв'язати проблеми у своєму колі. Формування угрупувань взагалі помітно змінює агресивну поведінку школярів. Перебування в групі дає можливість відчути комфорт і захищеність, збільшення своїх можливостей. Молодші школярі емоційно вразливі. Наслідком цього буває зникнення страху покарання за прояв агресії, загострене бажання ствердитися в ролі повноправного учасника подій, зайняти в групі гідне місце. Тому жорстокість, руйнівництво й інші прояви ворожої деструктивності різко зростають серед учнів початкової школи [6].

Р. Берон і Д. Річадсон виділяють такі причини виникнення агресивної поведінки.

1. Взаємовідносини в сім'ї.

2. Приклади, запропоновані в мас-медіа.

3. Стосунки з однолітками [4].

Аналіз зарубіжної і вітчизняної наукової літератури дав змогу виділити основні фактори, що сприяють формуванню агресивної поведінки молодших школярів, які наведені на рис. 1. 


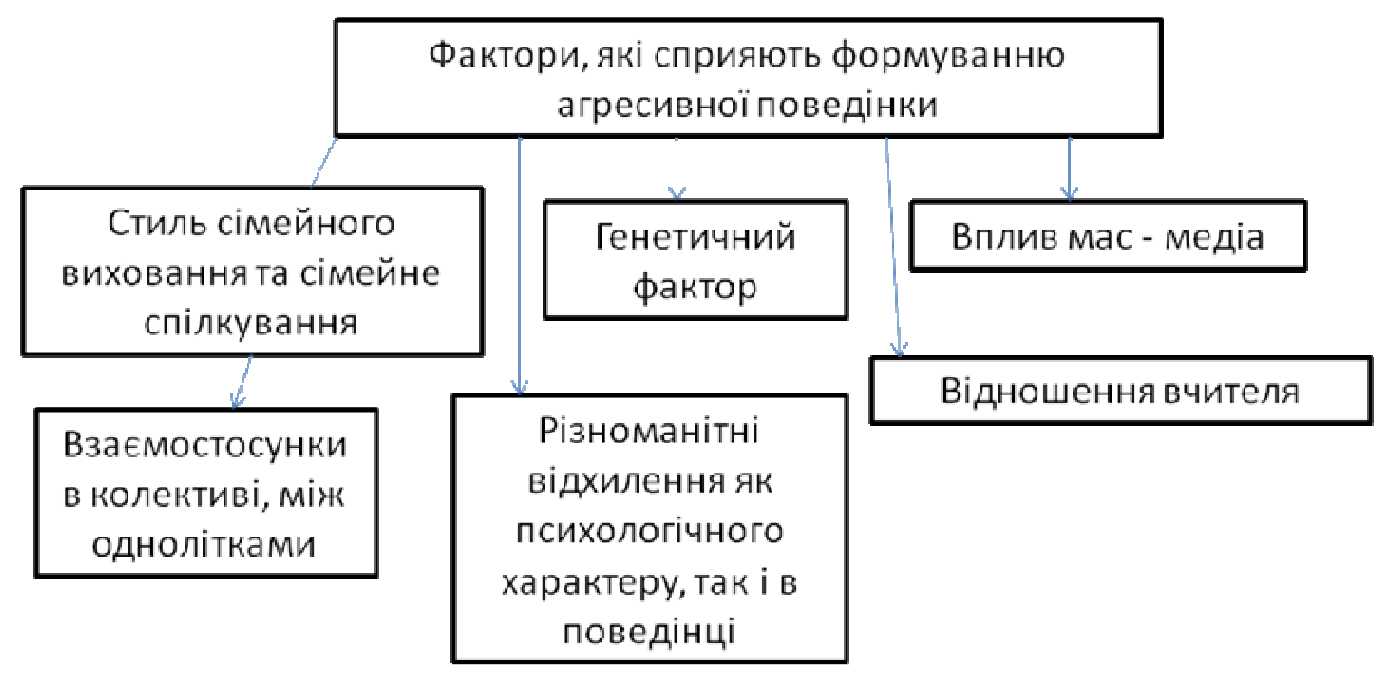

Рис. 1. Фактори, щуо сприяють формуванню агресивної поведінки

Одним 3 основних чинників, що впливає на формування агресивної поведінки дитини, є соціальні умови розвитку особистості, серед яких значне місце посідає сімейний фактор, генетичний фактор, а також вплив засобів масової інформації i відношення вчителя.

А. Реант і С. Костроміна [16] причинами агресивної поведінки дітей вважають, у першу чергу, копіювання поведінки батьків; по-друге, научання агресії в процесі безпосереднього набуття негативного досвіду, участь, а не пасивне спостереження; потретє, надмірне захоплення відео, телебаченням, комп'ютерними іграми.

Відомо, що сучасний ринок комп'ютерної продукції заповнений програмами, які вимагають від користувача актуалізації агресивної поведінки (ігри типу «Wolfenstein», «Doom», «Unreal», «Mortal Combat»). Існують дані, що до $85 \%$ американських комп'ютерних ігор відрізняються жорстокістю [5]. Тобто агресія у віртуальному світі виступає головною сюжетною лінією багатьох сучасних комп'ютерних ігор, a використання тактики «вигорілої землі» навіть часто рекомендується самими авторами ігрових програм [4]. Ця проблема, зокрема, була однією 3 центральних на VII-му Європейському Конгресі з психології, що проходив у 2001 році.

Аналіз робіт, присвячених проблемі взаємозв'язку «агресивних» ігор й агресії дітей і підлітків, дозволяє констатувати сильну поляризацію думок їх авторів: одні 3 них доводять наявність такого зв'язку, інші заперечують його. $С$ дані про те, що у піддослідних, які грали у віртуальні війни, спостерігалось підвищення фізіологічного збудження й агресивних думок. Доведеним фактом вважається підвищення агресивності у молодших школярів, які грають в ігри з елементами насильства [4].

Л. Берковітц також вказує на те, що проста наявність речей, пов'язаних $з$ агресією (наприклад, зброя), може провокувати агресивну поведінку людей. Як зазначав з цього приводу дослідник, «палець тисне на курок, але й курок може тиснути на палець» [4].

Саме тому робота вчителя має бути спрямована не лише на навчання учнів, але й на попередження таких проблем.

Важливість позитивних емоційних стосунків молодшого школяра i вчителя В. Мухіна пояснює тим, що це особливий тип взаємостосунків, тому що вчитель не просто доросла людина, яка викликає або не викликає симпатію дитини, він $є$ посередником між учнем і знаннями, які одержує учень [20]. Дітям властиві наслідування й підвищене навіювання, що як позитивно, так і негативно впливають на засвоєння норм і правил поведінки. У зв'язку з недостатнім розвитком самосвідомості діти можуть наслідувати небажані форми поведінки: грубість, недисциплінованість 
тощо. В інших випадках, коли вони беруть за взірець поведінку улюбленого вчителя, авторитетних для них дорослих, наслідування і підвищене навіювання полегшує засвоєння норм і правил поведінки. У цей період зростає роль особистого прикладу дорослих, передусім учителя [17].

Отже, для досягнення взаєморозуміння між учителем і дитиною й 3 метою попередження низки соціально-педагогічних проблем досить актуальним $\epsilon$ використання у роботі вчителя мультимедійних засобів і технологій.

На сьогоднішній день існує широкий спектр мультимедійних засобів, якими кожний учитель може користуватись у навчально-виховній роботі.

О. Мокрогуз [12] зробив спробу класифікації мультимедійних технологій навчального призначення, що використовують нині в освіті:

- інформаційно-пошукові й довідникові мультимедіа-системи;

- прикладні мультимедіа-енциклопедії;

- мультимедіа-засоби для контролю й вимірювання рівня знань, умінь і навичок школярів;

- електронні тренажери;

- мультимедіа-засоби для математичного й імітаційного моделювання;

- мультимедіа-засоби віртуальних лабораторій;

- автоматизовані навчальні системи;

- електронні мультимедіа-підручники,

- експертні навчальні системи;

- інтелектуальні навчальні системи.

До мультимедійних засобів належать мультимедійні додатки i засоби їх створення.

До мультимедійних додатків навчального призначення, що використовуються у загальноосвітньому навчальному закладі, можна віднести мультимедіа-презентацію, слайд-шоу, віртуальний тур; мультимедіа-видання, flash-, shockwave-ігри (навчальні ігри), мультимедіа-тренажери, навчальні мультимедіа-системи, лінгвістичні мультимедіа-системи, мультимедійні Internet-peсурси та інші [15].

Зупинимось на мультимедійних додатках, які сприяють попередженню агресивної поведінки учнів молодших класів.

Мультимедійні презентації - один із найбільш поширених засобів унаочнення навчального матеріалу, адже у ньому наявні не лише текст і графіка, але й анімація, відео і звук. Використання мультимедійних презентацій дозволяє вчителю зручно й ефективно візуалізувати статичні й динамічні дані [13].

Для створення презентації педагог може скористатися добре відомими програмними засобами - Microsoft PowerPoint, Macromedia Flash, Picasa та іншими. Зокрема, програма Picasa дозволяє легко виокремлювати статичні й динамічні зображення з Інтернету, зручно і швидко проектувати як слайд-шоу, так і навчальні фільми, додавати до проекту текстові й звукові коментарі, створювати колажі із статичних зображень. Мультимедійні презентації допомагають підкріпити словесний текст наочністю. Наприклад, якщо педагог прагне донести до учнів відомості про гармонійні стосунки між однолітками, то можна використати презентацію, показавши переваги дружніх стосунків у школі за допомогою фото, аудіо- та відео-фрагментів.

Під час створення мультимедійних презентацій необхідно враховувати таку послідовність, як мотивація, постановка навчальної мети, створення передумов до сприйняття навчального матеріалу, подання самого навчального матеріалу та його оцінювання. У створенні мультимедійної презентації потрібно враховувати не тільки відповідні принципи класичної дидактики, але і специфічні принципи використання комп’ютерних мультимедійних продуктів. 
Основою будь-якої мультимедійної презентації $є$ сюжетна лінія, сценарій та навігаційна структура. Навігаційна структура $є$ особливою рисою мультимедійних презентацій, оскільки забезпечує користувачеві можливість безпосередньо керувати процесом показу мультимедіа (інтерактивність). До елементів інтерактивності можна віднести використання гіперпосилань і кнопок дій. За допомогою засобів навігації можна, наприклад, організувати швидкий доступ до потрібних даних і переміщення до потрібного слайду або розділу [13].

Мультимедіа-тренажери - це навчально-тренувальні програмні продукти, що орієнтовані на відпрацювання учнями певних умінь й набуття загально біологічних і спеціальних навичок. Відмінність сучасних тренажерів від традиційних полягає в можливості імітувати різні життєві й навчальні ситуації, використовуючи технології мультимедіа, зокрема, високоякісну анімацію, тривимірну (3D) графіку, музику MIDI (Musical Instrument Digital Interface), цифровий інтерфейс музичних інструментів (стандарт, що дозволяє приєднувати до комп’ютера цифрові музичні інструменти) тощо [9].

Мультимедіа-тренажери в даний час $\epsilon$ доступним i поширеним засобом підготовки фахівців різного рівня кваліфікації. Широкі можливості комп'ютерних технологій у поєднанні з істотно меншими фінансовими витратами роблять цей напрямок вельми привабливим для начальних закладів.

Розроблення комп'ютерних ситуаційних тренажерів 3 використанням мультимедійних технологій створює можливість реалізувати практично будь-які за складністю експерименти з обладнанням і відтворити методики відпрацювання будьяких позаштатних ситуацій. Застосування сценарних моделей подання даних предметної області дозволяє запропонувати рішення для проектування і створення ефективних тренажерних комплексів, що засновані на моделях поведінки і сприйняття користувача та мають низку інтелектуальних функцій.

Використання мультимедійних тренажерів забезпечує програвання різних ситуацій і можливість самостійно розв'язати ту чи іншу проблему.

Flash-, shockwave- ігри (навчальні ігри) - комп'ютерна програма, що служить для організації ігрового процесу, зв'язку з партнерами по грі, або сама виступає як партнер. Комп'ютерні ігри класифікуються за чотирма ознакам [15]:

1) жанром (успадкованій сукупності певних тем і мотивів, закріпленої за певною художньою формою);

2) кількістю гравців і способу їх взаємодії (способом включення гравця в дію самостійно або одночасно з іншими гравцями);

3) тематикою (моделювання альтернативного варіанту розвитку);

4) платформою (приналежності до електронного пристрою, для якого розробляється гра).

Усі навчальні програми для молодшого віку можна поділити на такі класи:

- розвивальні ігри - це можуть бути різноманітні графічні редактори (для малювання, розфарбовування), конструктори малюнка, текстові редактори, конструктори казок, які поєднують можливості текстового і графічного редакторів;

- ігри навчального призначення - це програми, у яких в ігровій формі передбачається розв'язати одне або декілька дидактичних завдань (для формування математичних уявлень, навичок письма, читання, вивчення іноземної мови, орієнтування в просторі та інші);

- ігри-експериментування - це ігрові завдання, до розв'язку яких можна прийти шляхом пошуку дій; 
- ігри-розваги - у таких іграх немає ігрового завдання і завдання розвитку, просто вони дають можливість розважитися;

- комп'ютерні діагностичні ігри - це реалізовані у вигляді комп'ютерної програми психодіагностичні методики [2].

У монографії Д. Галкін [15] відзначає, що в культурній антропології гру представлено як свого роду культурну спадщину, свідоцтво минулого, що зберегло значення в сучасності, щоправда лише як ігрова умовність. Ігри завжди $\epsilon$ віддзеркаленням суспільства в конкретний історичний період - коли змінюється культура, змінюються і гри. Наразі на психологічному рівні вони $є$ моделями психічного життя людини. Ігри настільки універсальні, що претендують на те, щоб бути драматичними моделями світу, які найчастіше перетворюються в колективні художні форми.

Науковці, визначаючи роль ігор у житті людини, говорять про те, що є широкий діапазон проявів: гра як розрядка життєвої енергії; як вид відпочинку; як тренування перед серйозною справою; як вправа у прийнятті рішень; як реалізація прагнень до змагання і суперництва [15]. Будь-яка гра є вільною діяльністю. Гра за наказом стає нав'язаною імітацією, позбавляється головного сенсу і призначення. Грою зайняті у вільний час, вона не диктується необхідністю й обов'язком, а визначається бажанням, особистим настроєм. Можна вступити в гру, але можна і не робити цього, відкласти це заняття на невизначений термін. У повсякденному житті гра виникає як тимчасова перерва, як заняття для відпочинку, створюючи настрій радості. Але іiі цілі не пов'язані 3 користю, вигодою, матеріальним інтересом. Вона знаходить сенс і значення завдяки своїй самоцінності. Людина дорожить цим станом, згадуючи насолоду, яку вона пережила під час гри, бажаючи знову відчути ті ж почуття.

I. Югай, аналізуючи місце, яке займають ігри в житті людини, приходить до висновку, що комп'ютерна гра є нині найпоширенішим і послідовним прикладом «відкритого твору» - гра не зводиться до відтворення готового результату, бо їі задум втілюється через участь глядача [15]. Комп'ютерна гра синтезує інтелектуальну і творчу діяльність, яка передбачає здатність режисерувати, малювати, моделювати, анімувати та ін. Вона змінює місце і роль гравця у світі, пропонує йому нові соціальні ролі, життєві цілі і принципи поведінки. Під час комп'ютерної гри учасник знаходить вміння і здатність впливати на своє місце в сучасному житті, так як у процесі гри йому пропонується знайти нову соціальну роль, життєві позиції. І. Югай [15], беручи до уваги комп'ютері ігри, каже про те, що вони містять класичні властивості гри i захоплюють глядача можливістю відокремлення від повсякденного життя світом віртуальної реальності, у якому людина бере активну участь за рахунок використання різних форм інтерактивності.

Комп’ютерні ігри часто викликають серйозні адикції, бо інтерактивність створює ілюзію "легкості вчинення дій" без будь-якої моральної рефлексії. Насильство над людиною є аморальним, і перетворення його у віртуальну розвагу суперечить засадам $\mathrm{i}$ цінностям культури.

Навчальні фільми та відео демонстрації - це спеціально підготовлені аудіовізуальні засоби навчання, призначені для створення різноманітних ситуацій, що мають велику силу емоційного впливу на учнів за рахунок синтезу основних видів наочності (зорової, слухової, моторної, образної, екстралінгвістичної) [14]. Вони сприяють закріпленню отриманих знань, створюючи яскраві опорні моменти, допомагають засвоїти і систематизувати вивчений матеріал тощо.

Навчальні фільми і відео демонстрації можна переглядати повторно, повертаючись або зупиняючись на ключових фрагментах. Вони є дуже популярними серед викладачів історії, географії, хімії, біології тощо. Адже за допомогою навчальних 
фільмів можна донести безліч відомостей, скорегувати поведінку й особистісні якості дитини.

Аналіз наукової літератури дав змогу обгрунтувати актуальність застосування мультимедійних засобів у роботі 3 молодшими школярами. Адже використання описаних вище та інших видів мультимедійних технологій сприяє значній активізації навчально-пізнавальної діяльності учнів, розвитку їх самостійності, творчого потенціалу, інтелектуальних здібностей, профілактиці різноманітних соціальнопедагогічних проблем, зокрема попередженню агресивної поведінки.

\section{4. ВИСНОВКИ ТА ПЕРСПЕКТИВИ ПОДАЛЬШИХ ДОСЛІДЖЕНЬ}

Проаналізувавши наукові джерела, визначено, що використання мультимедійних засобів $є$ необхідною складовою в освітньому просторі. Кожний школяр має домашній комп'ютер, смартфон, мобільний телефон, планшет, за яким проводить значний проміжок свого вільного часу. Комп'ютерні ігри, фільми, прослуховування музики - це перше, чим цікавиться підростаюче покоління.

Аналіз зарубіжної і вітчизняної наукової літератури дав змогу визначити поняття «агресія» й «агресивна поведінка». Агресія формує агресивність як стійку рису особистості, а й, у свою чергу, сприяє виявленню агресивної поведінки.

Проблема агресивної поведінки молодших школярів виступає однією 3 найголовніших проблем нашого суспільства. Адже, як зазначають більшість дослідників, одним із чинників, що сприяють формуванню агресивної поведінки дітей, $\epsilon$ вплив засобів масової інформації, комп'ютерних ігор, перегляд фільмів, мультфільмів, які провокують агресію.

Одним із важливих напрямів роботи у попередженні агресивної поведінки молодших школярів $є$ підвищення компетентності вчителів, соціальних педагогів, психологів у використанні мультимедійних засобів 3 метою організації соціальнопедагогічної діяльності.

Отже, підсумовуючи вищезазначене, наголосимо, що мультимедійні засоби навчання дозволяють учителям використовувати можливості мультимедіа у початковій школі. Використання мультимедійних презентацій, тренажерів, навчальних фільмів, відео фрагментів й навчальних ігор сприятимуть підвищенню обізнаності учнів, розвитку особистісних якостей дитини. Застосування вчителем і соціальним педагогом мультимедійних засобів навчання 3 метою попередження агресивної поведінки дозволить підвищити ефективність процесу засвоєння знань i розвитку дитини в цілому.

У подальших дослідження доцільно дослідити методику застосування мультимедійних засобів у соціально-педагогічній роботі з молодшими школярами.

\section{СПИСОК ВИКОРИСТАНИХ ДЖЕРЕЛ}

1. Аверин В. Л. Психология детей и подростков : учеб. пособ. / Аверин В. Л. - СПб. : [б. и.], 1998. $-379 \mathrm{c}$.

2. Андрієвська В. М.. Мультимедійні технології у початковій ланці освіти : збірник-тез [Електронний ресурс] / В. М. Андрієвська, Н. В. Олефіренко // Інформаційні технології і засоби навчання. 2010. - №2 (16). - Режим доступу до збірника : http://ru.scribd.com/doc/184939111.

3. Бандура А. Подростковая агрессия. Изучение влияния воспитания и семейных отношений / А. Бандура, Р. Уолтерс ; пер. с англ. Ю. Брянцевой, Б. Красовского. - М. : Апрель Пресс ; Изд-во ЭКСМО-Пресс, 1999. - 512 c. 
4. Бэрон Р. Агрессия : учеб. пособ. / Р. Бэрон, Д. Ричардсон. ; пер. с англ. С. Меленевская, Д. Викторова, С. Шпак. - СПб. : Питер, 2001. - 352 с.

5. Болескина Е. Потребители игровой компьютерной культуры / Е. Болескина // Социологические исследования. - 2000. — № 9. - С. 80-87.

6. Бреслав Г. М. Эмоциональные особенности формирования личности в детстве / Бреслав Г. М. М. : [б. и.], 1991. - 144 с.

7. Гончаренко С. У. Український педагогічний енциклопедичний словник / С. У. Гончаренко. [Видання друге, доповнене й виправлене]. - Рівне : Волинські обереги, 2011. - 552 с.

8. Жук Ю. О. Моніторинг рівня навчальних досягнень 3 використанням Інтернет-технологій: монографія / Биков В. Ю., Богачков Ю. М., Жук Ю. О. / за ред. В. Ю. Бикова, член.-кор. АПН України, д. тех. наук, проф.; Ю. О. Жука, канд. пед. наук, доц. - К. : Педагогічна думка, 2009. $128 \mathrm{c.}$

9. Імбер В. І. Педагогічні умови застосування мультимедійних засобів навчання у підготовці майбутнього вчителя початкових класів : автореф. дис. на здобуття вчен. ступеня канд. пед. наук :спец. 13.00.04 «Теорія і методика професійної освіти» / В. І. Імбер. - Вінниця, 2008. - 20 с.

10. Казаков Ю. М. Педагогічні умови застосування медіаосвіти в процесі професійної підготовки майбутніх учителів : автореф. дис. на здобуття наук. ступеня канд. пед. наук: спец. : $13.00 .04-$ теорія та методика професійної освіти / Ю. М. Казаков. - Луганськ, 2007. — 21с.

11. Коваленко В. В. Проблеми підготовки вчителя i соціального педагога до застосування мультимедійних засобів для формування основ здоров'я молодших школярів [Електронний ресурс] / В. В. Коваленко // Інформаційні технології і засоби навчання. — 2013.— №5 (37). Режим доступу до збірника : http://journal.iitta.gov.ua/index.php/itlt/article/view/879.

12. Корнєв В. П. Використання інформаційно-телекомунікаційних технологій : зб. наук. праць / В. П. Корнєв - К. : ДНВП : «Картографія», 2008. - С. 50-53 с.

13. Методичні рекомендації щодо проведення презентацій / [упоряд. I. М. Церебрякова]. Дніпропетровськ : КЗ “Дніпропетровська обласна науково-методична бібліотека”, 2010. - 14 с.

14. Смирнов I. Б. Розвиток усного мовлення учнів на основі автентичного художнього фільму / I. Б. Смирнов // Іноземні мови в школі. - 2006. - № 6. - С. 11-14.

15. Сучасні технології електронних мультимедійних видань : [зб.наук.праць / наук. ред. Пушкарь О. I.]. - Харків : ВД «ІНЖЕК», 2011. - 296 с.

16. Смирнова Т. П. Психологическая коррекция агрессивного поведения детей. Серия «Психологический практикум» / Смирнова Т. П. - Ростов н/Д : «Феникс», 2004. - 160 с.

17. Паренс Г. Агрессия наших детей / Паренс Г. - М. : [б. и.], 1997. - 182 с.

18. Пінчук О. П. Актуальні проблеми використання засобів мультимедійних технологій в основній школі / О. П. Пінчук // Нові технології навчання : наук.-метод. зб. / [Кол. авт.]. — К. : Інститут інноваційних технологій і змісту освіти, 2007. - Вип. 47. - С. 107-111.

19. Платонова Н. М. Агрессия у детей и подростков : учеб. пособ. / Платонова Н. М. - СПб. : Речь, 2006. - $336 \mathrm{c}$.

20. Российская педагогическая энциклопедия в двух томах / [ред. Ю. Н. Короткова и др.].- М. : «Большая Российская енциклопедия», 1993. - 119 с.

21. Селевко Г. К. Современные образовательные технологии : учеб. пособ. для пед. вузов и ин-тов повышения квалификации / Г. К. Селевко. - М. : Народное образовании, 1998. - 256 с.

Матеріал надійшов до редакиії 15.09.2014 p.

\title{
АКТУАЛЬНОСТЬ ИСПОЛЬЗОВАНИЯ МУЛЬТИМЕДИЙНЫХ СРЕДСТВ С ЦЕЛЬЮ ПРЕДУПРЕЖДЕНИИ АГРЕССИВНОГО ПОВЕДЕНИЯ МЛАДШИХ ШКОЛЬНИКОВ
}

\author{
Олексюк Наталья Васильевна \\ заведующий отделом кадров \\ Институт информационных технологий и средств обучения НАПН Украины, г. Киев, Украина. \\ natawaoleksuk@ukr.net
}

Аннотация. В публикации проведен анализ проблемы агрессивного поведения младших школьников и причины его возникновения. Определены преимущества использования мультимедийных средств в предупреждении агрессивного поведения школьников и описаны разновидности мультимедийных средств, которые целесообразно применять в 
работе с младшими школьниками. Проблема агрессивного поведения младших школьников выступает одной из главных проблем нашего общества. Как отмечают большинство исследователей, одной из причин агрессивного поведения детей выступают именно средства массовой информации и использования игр, просмотр фильмов, мультфильмов, которые провоцируют агрессию. Одним из важных направлений работы в предупреждении агрессивного поведения младших школьников является повышение компетентности учителей, социальных педагогов, психологов в использовании мультимедийных средств с целью проведения для школьников социально-педагогических занятий.

Ключевые слова: агрессия; агрессивное поведение; мультимедийные средства; младшие школьники.

\title{
RELEVANCE OF USE OF MULTIMEDIA IN ORDER TO PREVENT JUNIOR PUPILS' AGGRESSIVE BEHAVIOUR
}

\author{
Natalia V. Oleksiuk \\ head of Human Resources Department \\ Institute of Information Technologies and Learning Tools of NAPS of Ukraine, Kyiv, Ukraine. \\ natawaoleksuk@ukr.net
}

\begin{abstract}
The article analyzes the problem of aggressive behaviour of junior pupils and reasons for its occurrence. There are determined advantages of multimedia use in the prevention of aggressive behaviour of junior pupils and described types of multimedia, which should be used to work with pupils. Problem of aggressive behaviour of junior pupils become one of the main problems of our society. As noted by the most researchers, one of the cause of aggressive behaviour of junior pupils is media, the use of video games, watching movies, cartoons that provoke aggression. One of the important areas of prevention of aggressive behaviour of junior pupils is competence improvement of teachers, social workers and psychologists on the use of multimedia in social and educational classes for junior pupils.
\end{abstract}

Keywords: aggression; aggressive behaviour; multimedia; junior pupils.

\section{REFERENCES (TRANSLATED AND TRANSLITERATED)}

1. Averyn V. L Psychology children and adolescents: tutorial / V. L. Averyn. - St. : [B. s.], 1998. - 379 p. (in Ukrainian).

2. Andriewska V. M. Multimedia technologies in primary level of education [online] / V. M. Andriewska, N. V. Olefirenko // Information technologies and learning tools. - 2010. - № 2 (16). - Available from : http://www.ime.edu.ua.net/em.html. (in Ukrainian).

3. Bandura A. Teenager agresiya. Study of the influence of education and family relations / A. Bandura, R. Walters; Lane. with the English. Bryantsevoy Yu, B. Krasovskoho. - M.: April Press; publishing Eksmo-Press, 1999. - 512 p. (in Russian).

4. Beron R. Aggression: tutorial / Beron R., D. Richardson. , Lane. with the English. Melenevskaya S., D. Viktorov, S. Spak. - St. : P., 2001 - 352 p. (in Russian).

5. Boleskyna E. Consumers computer gaming culture / E. Boleskyna // sociological study. - 2000. - № 9. S. 80-87. (in Russian).

6. Braslaw G. M Emotional characteristics of identity formation in childhood / Braslaw G. M - M. : [b. s.], 1991. - 144 p. (in Russian).

7. Goncharenko S. U. Ukrainian Pedagogical Encyclopedic Dictionary / S. U. Goncharenko. - [Second edition, supplemented and revised]. - Rivne : Volyntalismans, 2011. - 552 p. (in Ukrainian).

8. Zhuk Yu. O. Means of education / EntsiklopedIya osviti. - APN Ukrayini; gol. red. V. G. Kremen. - K. : YurInom Inter, 2008. - S. 313-314. (in Ukrainian).

9. Imber V. I. Pedagogical Conditions of Use of Multimedia Learning Tools inFuture Primary School Teacher Training : candidate dissertation autoabstract : 13.00.04 «Theory and Methods of Professional Education» / Imber V. I. - Vinnytsya, 2008. - 20 p. (in Ukrainian).

10. Kazakov M. Pedagogical conditions of use of media education in the training of future teachers: Author. Thesis. for obtaining sciences. degree candidate. ped. sciences special .: 13.00.04. - Theory and Methods of Professional Education. / Y. M Kazakov. - Lugansk, 2007. - 21 p. (in Ukrainian). 
11. Kovalenko V. Problems of teachers and social workers to use multimedia tools for laying the foundations of health primary school children [online] / V. V Kovalenko // Information technology and learning tools. - 2013. - №5 (37). - Available from: http://journal.iitta.gov.ua/index.php/itlt/article/view/879 (in Ukrainian).

12. Kornyev V. P Information and communication technologies: Coll. sciences. works / V. P Kornyev - K SSPE: "Cartography", 2008 - 50 - 53 p. (in Ukrainian).

13. Guidelines for presentations / [compiled. I. M Tserebryakova]. - Dnipropetrovsk: BB "Dnipropetrovsk regional scientific-methodical Library", 2010 - 14 p. (in Ukrainian).

14. Smirnov B. Development of speech students on the basis of feature film / I. B Smirnov // foreign language in school. - 2006. - № 6. - S. 11-14. (in Russian).

15. Modern technologies of electronic publications multimedia edition: [Coll. Science. works. / science. red. Pushkar O.I]. - Kharkiv : ID "INZHEK", 2011. - 296 p. (in Ukrainian).

16. Smirnova T. P Psychological correction of aggressive behavior in children. Series "Psychological Workshop" / Smirnova T. P. - Rostov N / D: "Phoenix", 2004. - 160 p. ( in Russian).

17. Parens H. Aggression of our children / Parens H. - M. : [b. s.], 1997. - 182 p. (in Russian).

18. O. Pinchuk Actual problems the use of multimedia technology in the elementary school / O. Pinchuk // New learning technologies: scientific-method. Zagreb. / [Num. auth.]. - Kyiv : Institute of Innovative Technology and Education, 2007 - Vol. 47 - S. 107-111. (in Ukrainian).

19. Platonova N. Aggressions in children and adolescents: tutorial / Platonova N. M. - St. : Speech, $2006-$ 336 p. (in Russian).

20. Russian Pedagogical Encyclopedia in two volumes / [red. N. Korotkov]. - M. "Bolshaya Rossiyskaya entsyklopedyya", 1993. - 119 p. (in Russian).

21. Selevko G. K. Modern educational technology : tutorial for Colleges and Institutes / G. K. Selevko. - M. : Narodnoe Education, 1998. - 256 p. (in Russian). 